\title{
Effect of Financial Performance against Financial Distress through Risk in Islamic Banks
}

\author{
Jumirin Asyikin ${ }^{1}$, Grahita Chandrarin ${ }^{2}$, Harmono ${ }^{3}$ \\ ${ }^{1}$ Doctoral Program University of Merdeka Malang, \\ STIE Indonesia Banjarmasin, Indonesia \\ ${ }^{2.3}$ University of Merdeka Malang, Indonesia
}

\begin{abstract}
This study aimed to analyze the influence of financial performance (ROA, ROE, FDR and BOPO) against risk; analyze the influence of financial performance (ROA, ROE, FDR and BOPO) and the Risk to Financial Distress, and to analyze the influence of financial performance (ROA, ROE, FDR and BOPO) of the Financial Distress through Risk Probability. Mechanical analysis using Partial Least Square (PLS). The analysis showed that the effect on the financial performance of risk, which means that the poor financial performance can increase the risk. Financial distress is affected by financial performance risk. Risk mediating influence the financial performance of the stock price. Better financial performance reflects the performance of a particular period can reduce financial distress.
\end{abstract}

Keywords: Financial Performance, Risk, Financial Distress.

\section{INTRODUCTION}

The existence of Islamic banks is indispensable people, especially to be able to avoid or eliminate the practice of banks based on interest (riba). Interest in the concept of Islam is synonymous with usury. This is in accordance with the MUI Fatwa No. 1/2004 on Flowers (Intersat / Fa'idah), dated January 24, 2004. Later the regulations of the government, among others, by the issuance of Law No. 7 of 1992 concerning Banking conjunction with Law No. 10 of 1998 on the BUS, including branches of banks domiciled abroad. While specific to the BUS (Islamic banks) and UUS (Islamic business unit), PBI 09/19 / PBI / 2007 regarding the implementation of Sharia in the activities of Collection and Distribution of Funds and Islamic Banking Services, and has been issued law No. 21 of 2008 concerning Sharia Banking.

Islamic Bank as one of the banks that serve the people must run Islamic principles consistently. Not only the management of public funds and the provision of the regulation of the government and the other, but also must consider the level of profitability. Because of this profitability can be done to maximize profits. That is by running the intermediation function and funding from society based on Islamic principles (contract mudaraba, murabaha, Musharaka, Ijara, greetings, istisnaa, other banking services as well as qardul hasan). Based on the contract, Islamic banks can sell their products to customers in the form of demand deposits, savings and time deposits. In operation for the collection and distribution of funds, Islamic banks can play a role as a manager (mudharib) and the owner of the funds (Shohibul mall). Hassoune, that the results make the bank much more efficient because of the availability of non remunerad deposit large amounts of funding that can reduce expenses. Islamic banks which apply the principle of sharing the intermediary function can reduce operational efficiency [1]. Meanwhile, Ramlan and Adnan, The study found that Islamic banks more profitable than conventional banks, while total loans to total assets of Islamic banks is higher than in conventional banks [2].

This study was inspired by research conducted by Kurniawansyah, By collaborating on several other studies, such as updating the study variables and add a few variables, one variable is financial distress [3]. Financial distress is a condition in which there is a decrease periodically the financial condition. This marks the beginning of bankruptcy or liquidation conditions. Rahman and Masngu, that all Islamic banks have ETA ratio (total assets) higher that describe the performance is well capitalized and less likely to face the problem of financial hardship [4]. Regarding asset quality, all Islamic banks are not likely to face financial pressures because they are able to deal with their problem loans throughout the year. According toPlatt and Platt, That the usefulness of the information if a company experiencing financial distress there are three things: 1) Speed management measures to prevent problems before bankruptcy. 2) The management can immediately take action to carry out a merger or takeover. 3) Provide a warning sign (signal) earlier on the possibility of bankruptcy for the foreseeable future [5]. In addition, this study builds on several previous studies, among others carried out by Rahman, based on the ratio and shari'ah compliance ratio (CAMELS) that an Islamic bank in Malaysia showed a good performance [4]. Kurniawansyah, that the efficiency of an intervening variable and the risk is not an intervening variable profit-loss sharing relationship profit sharing funding and financing in relation to the level of profitability [3]. Dhiyaul-Haq and Santoso, profitability, rewards and BUS partial ownership type does not affect the disclosure of ISR (Islamic Social Reporting). Several factors are relevant to the likelihood of financial distress in the United Arab Emirates (UAE), according to Zaki et al, is: 1) capacity, the ratio of expenses to income (CIF). 2) capital, the ratio of 
capital to total assets. 3) guarantee (collateral), total asset growth, and 4) the conditions (internal), indicate the credit risk (represented by nonperforming loans to total loans) [6]. Then the macro economic factors do not significantly affect the financial distress of the financial institutions in the UAE. Ismawati suggested that the Capital Adequacy Ratio (CAR) has no effect on the probability of Banking Financial distress [7].

Therefore, the operations of Islamic banks should be able to manage funds efficiently, minimize risk, maximize profit to increase revenue sharing. The continuity of the bank's operations can run well then the management should pay attention to risk factors (investment) and can detect the possibility of financial distress early. According to Kazmi, the risk is the probability of the likelihood of the situation worsening (bad outcomes) that can be detrimental to the bank. This can be seen from the achievement level of profibitabilitas, does indicate a positive or negative trend. For banks in acquiring profit orientation must be accompanied by a good bank management in accordance with Islamic principles and provisions of the government of the Republic of Indonesia (Financial Services Authority / FSA and or Bank Indonesia). Therefore, According Hosen and Tone, With CAMEL found that the three Islamic banks examined are categorized as healthy, however, the results of Multiple Discriminant Analysis (MDA) said the three banks were in a state of bankruptcy [8]. The conflicting findings indicate that MDA method was not appropriate to apply to the banks for the banks as a financial intermediary characteristics far different from the characteristics of the company. Therefore, in this case the management of Islamic commercial bank managers must be able to anticipate the possibility of financial distress, based on the analysis of financial performance through influence relationship between risk.

This study aimed to analyze the influence of financial performance (ROA, ROE, FDR and BOPO) against risk; analyze the influence of financial performance (ROA, ROE, FDR and BOPO) and the Risk to Financial Distress, and to analyze the influence of financial performance (ROA, ROE, FDR and BOPO) of the Financial Distress through Risk Probability.

\section{LITERATURE REVIEW}

\subsection{Financial Distress}

financial distress is a condition of companies that experience illiquid but still in a state of solvents. Here are some definitions that financial distress; according to Hanafi and Halim, financial distress can be drawn from the two extremes, namely short-term liquidity problem until insolvable [9]. Short-term financial difficulties are usually short-term, but it can develop into severe. Indicators of financial difficulties can be seen from the cash flow analysis, analysis of the company's strategy, and the company's financial statements. According to Fahmi defines financial distress as a stage of decline in financial condition that occurs prior to the bankruptcy or liquidation. Financial distress begins with the inability to meet its obligations [10].

\subsection{Financial performance}

According to Mulyadi, the financial performance represents the performance obtained from the company's performance using debt [11]. Therefore, the use of debt is expected to improve the company's performance. If the debt is used to improve the performance of the company, then the use of debt to benefit the company. Furthermore, according to the company's financial performance Helfert is the result of many individual decisions are made constantly by the management. To assess the performance of the company should be involved analysis of the cumulative financial and economic impact of the decision, and consider using a comparative measure [12].

\subsection{Risk}

Risk according to Idroes (is a threat or risk the possibility of an action or event giving rise to the opposite effect to the objectives to be achieved. In bank has various types of risk which consists of 8 (eight) the risk that credit risk, market risk, operational risk, liquidity risk, risk Legal, Strategic risk, compliance risk and reputation risk.credit riskis a risk due to the failure of the debtor and / or other parties to meet obligations to the bank [13]. Credit risk is generally present in all activities of the bank whose performance depends on the performance of counterparty (counterparty), publisher (issuer), or the performance of borrowers (borrowers). Credit risk can also be caused by the concentration of provision of funds to the debtor, geographic region, product, type of loading, or certain business field. This risk is commonly called the Credit Risk Concentration and shall be calculated also in the inherent risk assessment.

\subsection{Hypothesis}

The hypotheses are as follows:

$\mathrm{H}_{1}$ : Financial performance (ROA, ROE, FDR and BOPO) significantly influences the risk.

$\mathrm{H}_{2}$ : Financial performance (ROA, ROE, FDR and BOPO) significantly influences Financial Distress.

$\mathrm{H}_{3}$ : Risk significantly influences Financial Distress.

$\mathrm{H}_{4}$ : Financial performance (ROA, ROE, FDR and BOPO) significantly influences Financial Distress through Risk.

\section{RESEARCH METHODS}

\subsection{Research Design}

Based on the formulation of the problems and objectives described in the previous chapter, this research is classified as cau sal research (causative). The causative is a research by using the characteristics of a causal relationship between two or more variables. This study examined the relationship between exogenous variables (X1, X2, X3, X4), namely intervening variables and endogenous variables Y1 (Y2). This study is in the form of quantitative research design. Secondary data analysis is based on information from the annual reports BUS. 


\subsection{The definition of Operations}

a. Financial Distress

Financial distress is a decrease in financial conditions that occur in the company prior to the bankruptcy. Variable financial distress was measured using a dummy with the following conditions:

1) A value of 1 when experiencing financial distress if the NPF ratio $\geq 5 \%$

2) A value of 0 when not experiencing financial distress or NPF ratio $<5 \%$.

b. Risk

Risk is the probability of the likelihood of unfavorable conditions that can harm the bank. This variable is measured by the following indicators:

a) Liquidity Risk ratio $=\frac{\text { Liquid }- \text { Assets - ShortTerm Borrowing }}{\text { Total Deposit }} \times 100 \%$

b) Deposits risk ratio $=\frac{\text { Equity Capital }}{\text { Total Deposit }} \times 100 \%$

c. Financial performance

The financial performance is an evaluation conducted to measure the performance of the financial sector on the performance of a company, which is done by comparing the financial performance with the average company. Financial performance using the following indicators:

1) Return on Assets (ROA)

ROA is the ratio used to determine the rate of return and the efficient management of assets owned by the bank, as measured by the formulation as follows:

$\mathrm{ROA}=\frac{\text { Net profit }}{\text { Total aset }} \times 100 \%$

2) Return on Equity (ROE)

ROE is a ratio used to assess the performance of the company and to measure the level of return on capital of the company.

$\mathrm{ROE}=\frac{\text { Net profit }}{\text { Equity }} \times 100 \%$

3) Financing to Deposit Ratio (FDR)

FDR is a bank's ability to repay depositors withdrawal of funds committed by relying on loans as a source of liquidity, is formulated as follows:

FDR $=\frac{\text { Loading }}{\text { Third - party fund }} \times 100 \%$

4) Operating Expense to Operating Income (BOPO)

BOPO is the ratio used to measure the ability of bank management in controlling operating expenses to operating income, as measured by the formulation as follows:

$$
\mathrm{BOPO}=\frac{\text { Total operating expenses }}{\text { Total operating income }} \times 100 \%
$$

\subsection{Population Sample Sampling Research and Engineering}

The population in this study is the BUS (Islamic banks) in Indonesia as many as 13 pieces of BUS, ie all Islamic banks. Sholihin and Ratmono, the sample size is basically no problem identification and fixed model can be estimated even with the small size (35-50) and can reach a high enough statistical power with small sample sizes [14]. The number of samples in this study as many as 13 banks, so that the sampling technique using a survey method.

\subsection{Data analysis technique}

The data in this study using the Partial Least Square (PLS), using analytical techniques multigrup. Path analysis (path analysis) is a type of analytical techniques used for testing the effect of independent variables on more than one dependent variable. This analysis is best used in the research of financial accounting and management accounting [15]. This analysis aims to compare the path coefficient for the same model but in different samples. The reasons for choosing PLS because it can be based on (a) theory, (b) the results of empirical research, (c) the analogy, the relationship between variables in other disciplines, (d) matters of normative, such as government regulations, laws and partly, (e) other rational relationship, so that the theoretical basis of the PLS can be strong,

\section{RESULTS AND DISCUSSION}

4.1. Result

The description of each variable can be presented in Table 1 below. 
International Journal of Advances in Scientific Research and Engineering (ijasre), Vol 5 (11), November-2019

Table 1 Description Statistics Research

\begin{tabular}{lrrrr}
\hline \multicolumn{1}{c}{ Variables } & \multicolumn{1}{c}{ Minimum } & \multicolumn{1}{c}{ Maximum } & \multicolumn{1}{c}{ Mean } & Std. deviation \\
\hline Financial performance & & & & \\
ROA & -20.13 & 99.77 & 9.10 & 26.03 \\
ROE & -32.04 & 102.70 & 12.98 & 25.07 \\
FDR & 0.44 & 157.77 & 87.18 & 28.43 \\
BOPO & 0.08 & 217.40 & 88.34 & 35.64 \\
Risk & & & & \\
LRR & 0,02 & 32.36 & 12.24 & 5.92 \\
DRR & 1.09 & 111.38 & 12.09 & 13.42 \\
FD & 0 & 1 & 0.71 & 0.46 \\
\hline
\end{tabular}

Source: Data processed.

ROA of -20.13 minimum value to a maximum of 99.77 , a mean of 22.48 with a standard deviation of 26.03 , it indicates that the value of ROA varies. This suggests that the ability of Islamic banks (assets) is able to generate an optimal profit. The higher the ratio of an Islamic commercial bank, the greater the ability of Islamic banks in the management of all its assets to generate earnings. ROA is low, indicating a protection for the lender against the possibility of liquidation. ROE is -32.04 minimum value to a maximum of 102.70 , a mean of 12.98 with a standard deviation of 25.07 , it indicates that the value of ROE varies. This shows that Islamic banks (equity) is able to generate the maximum profit from funds that have been granted by the shareholders, which means the financial performance of Islamic banks in good condition. The larger the ROE means Islamic banks more efficient to generate a profit from every unit of shareholders' equity. ROE shows how well an Islamic commercial bank uses investment funds to generate earnings growth. FDR minimum value of 0.44 to a maximum of 157.77 , a mean of 87.18 with a standard deviation of 28.43, it indicates that the value of FDR varies. The minimum value of the value of BOPO of 0.08 to a maximum of 217.40 , a mean of 88.34 with a standard deviation of 35.64 ,

LRR minimum value of 0.02 to a maximum of 32.36, a mean of 12.24 with a standard deviation of 5.92, suggesting that it indicates that the LRR vary. DRR minimum value of 1.09 to a maximum of 111.38 , a mean of 12.24 with a standard deviation of 13.42, suggesting shows that DRR is varied. Financial distress minimum value of 0 to a maximum of 1 , the mean was 0.71 with a standard deviation of 0.46 , suggesting that Islamic banks are likely to experience financial distress.

\subsection{PLS analysis}

Path models created to illustrate the relationship between the variables of financial performance, risk and financial distress. Path model in this study is also used to indicate the level of significance in hypothesis testing. Path models of this study are presented in Figure 1 below.

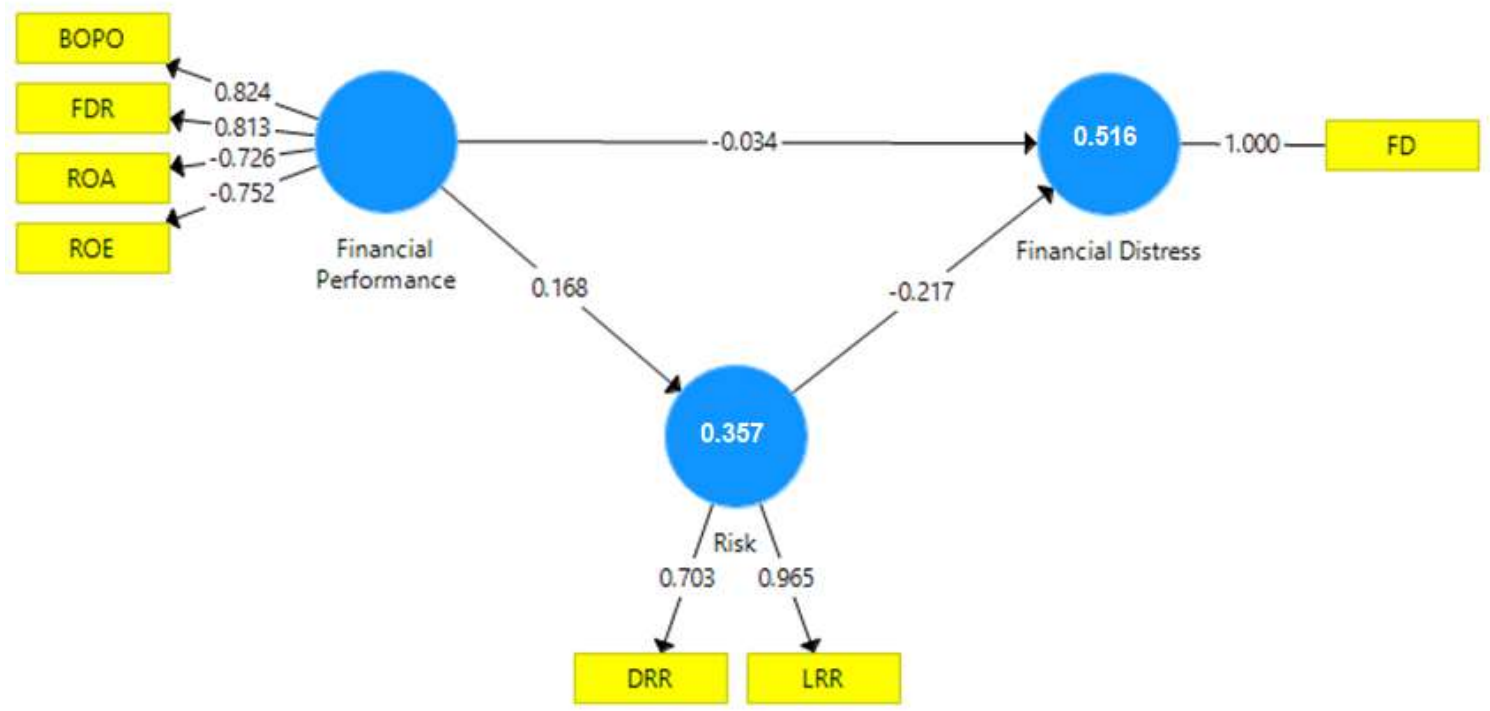

Picture 1 path Model

Figure 1 shows that the financial performance positively affect risk for 0.168 shares, financial performance negatively affect the financial distress of -0.034 . It can be concluded that the exogenous variables and mediating variables in this study had an influence on endogennya variable.

Goodness of fit model is one way that can be used to determine how big the endogenous variables are able to explain the diversity of exogenous variables. Through this model will be known to the contribution of exogenous variables on endogenous variables. Goodness of fit models in PLS analysis can be searched by using Q-square predictive relevance $\left(\mathrm{Q}^{2}\right)$. $\mathrm{Q}^{2}$ is an indicator to measure the relevance of predictive models. When PLS-SEM showing the relevance of predictive then $\mathrm{Q}^{2}$ will predict indicator data point in a reflective measurement model an endogenous construct. $\mathrm{Q}^{2}$ value> 0 is evidence that the observed values of the reconstructed properly so that the model has predictive relevance. $\mathrm{Q}^{2}$ value $<0$ indicates no predictive relevance. 
Table 2 Results Goodness of Fit Models

\begin{tabular}{|c|c|}
\hline Variables & $\mathbf{R}^{2}$ \\
\hline \multicolumn{2}{|l|}{ Financial performance } \\
\hline Risk & 0.357 \\
\hline Financial Distress & 0.516 \\
\hline$Q^{2}=1-\left(1-R_{1}^{2}\right)\left(1-R_{2}^{2}\right)=0.816$ & \\
\hline
\end{tabular}

Source: Data processed.

$\mathrm{R}^{2}$ risk variable has a value of 0.357 , this value means that the financial performance variables able to contribute $35.7 \%$ of the risk or it can also be said risks are able explained by the financial performance of $35.7 \%$. The remaining percentage of $64.3 \%$ is the contribution of other variables that are not part of this study. Financial distress variable $\mathrm{R}^{2}$ has a value of 0.516 , it means that the value of financial performance and risk variables were able to account for $51.6 \%$ of the financial distress or financial distress can also be said to be able to be explained by the variables of financial performance and the risk of $51.6 \%$. The rest of the percentage of $48.4 \%$ is the contribution of other variables that are not part of this study.

$\mathrm{Q}^{2}$ is worth 0,816 studies, these results imply diversity of financial variables capable distress described by the model of $81.6 \%$ overall. It can be said that the financial performance and risk variables can contribute to the diversity of financial distress by $81.6 \%$. The remaining percentage of $18.4 \%$ is the contribution of other variables that are not part of this study.

\subsection{Examination Hypothesis}

Testing the hypothesis in this study consists of two parts, the hypothesis testing direct and indirect hypothesis testing. The whole hypothesis testing was done using t-test for each effect, both effects of direct and indirect effect through mediating variables. Hypothesis testing results will be discussed in a row starting from the direct influence of the indirect as follows.

Table 3 Hasi Hypothesis Testing Indirect Influence

\begin{tabular}{clccc}
\hline Hypothesis & \multicolumn{1}{c}{ Relationship } & Path Coefficients & P-value & Information \\
\hline H1 & Financial performance $\rightarrow$ risk & 0.168 & 0,023 & Accepted \\
\hline H2 & Financial performance $\rightarrow$ Financial Distress & -0.034 & 0,040 & Accepted \\
\hline H2 & Risk $\rightarrow$ Financial Distress & -0.217 & 0,014 & Accepted \\
\hline H5 & Financial performance $\rightarrow$ risk $\rightarrow$ Financial Distress & -0.071 & 0,034 & Accepted \\
\hline
\end{tabular}

Source: processed data (2019).

According to the table above can be explained as follows:

1. The direct effectthe financial performance of the risk by 0.168 with $\mathrm{p}$ value of $0.023(\mathrm{p}<0.05)$ were significant. Thus the first hypothesis is statistically proven.

2. The results of the effect of the financial performance of the financial distress of -0.034 with $p$ value of 0.040 ( $p<0.05$ ) were significant. Thus the second hypothesis is statistically proven.

3. The results of the effect of risk to the financial distress of -0.217 with ap value of $0.014(p<0.05)$ were significant. Thus the third hypothesis is statistically proven.

4. The indirect effect on the financial performance of the financial distress throughrisk amounting to -0.071 with $p$ value of 0.034 is significant. Risks shown to mediate the effect of the financial performance of financial distress. Thus the fourth hypothesis is statistically proven.

\subsection{Discussion}

Financial performance affects the risk, which means that the poor financial performance can increase the risk. As opinions Kieso et al., that an analysis of the financial performance Islamic banks means describe the mathematical relationship between the sum of one with another sum in the form of a percentage (\%), rates or proportions that simple [16]. Analysis of the financial statements of an Islamic commercial bank aims to determine the level of benefits, the level of health and the level of risk an Islamic commercial bank in the data calculating financial performance Islamic banks. So that in conducting financial analysis will depend on the financial statements of three Islamic banks, namely: Balance Sheet (report financial position), Profit Loss and Cash Flow Statement. The results of this study are consistent with Purnamandari and Badera found that the financial performance such as BOPO is able to predict the risk of bank failure [17]. The size of the bank is able to predict the risk of bank failure. The banking industry is an industry that is fraught with risks, especially for meinvolve the management of public money and played in various forms of investment, such as loans, the purchase of securities and other fund investment. All the activities of both bank from the asset or liability contains various types of risk, whether it is market risk, credit risk, liquidity risk and other risks. The size of the risk will depend on various factors involved, such as the ability and foresight of management to manage risk management

Financial performance affects the financial distress. This suggests that the low height of the financial performance of Islamic banks to be the cause of financial distress. The demonstrated high ROE Islamic banks have the ability to use the equity to generate profit, and the better the bank's financial performance in internal funding sources for investment, so as to reduce the occurrence of financial distress, ROA is a bank force in generating profits with existing assets, so that when a high ROA ratio followed by a decline in financial distress. Banks that still have capital adequacy to risk and have sufficient liquidity and followed 
a great load management efficiency, the ROA ratio of impact to financial distress. Therefore, the high rate of decline will affect the financial distress is a condition where early stage sebuah bankruptcy. ROA is a ratio that shows how much the bank incurred operating expenses to operating income generated bank. Therefore, with this high ratio will affect the increase in financial distress which is a condition in which the early stages of a bankruptcy. With a significant relationship between BOPO and financial distress, so the BOPO ratio can be used as an Early Warning System to prevent financial distress in Islamic Banks. The results of this study are consistent with research Saleh and Sudiyatno which states that the ROA and ROE can predict the occurrence probability of bankruptcy on an Islamic commercial bank listed on the Indonesia Stock Exchange [18]. The results also konsiten with Baskoro which states that ROA and ROE affect the financial distress [19].

Affect the risk of financial distress, which means that high-risk indicates the condition of the banks that are less good, because the cost of running the bank's assets grew, giving rise to the potential for financial distress. Bank as a financial intermediary that is based on trust, risk management is very important in the banking world to suppress the occurrence of loss due to risks and strengthen the institutional structure. Better risk management for the bank to make sure the bank will be saved from destruction if a bad situation happens. With the increasingly complex risks in the banking industry, it is necessary to practice good risk management to avoid financial distress.

Risk mediating influence the financial performance of the stock price. The better financial performance reflects the performance of a specific period and if supported by Islamic banks can lower the efficiency of financial distress. Good financial performance can increase the benefits to be obtained by the investor. Generally, investors will look for Islamic banks that have the best performance and invest in Islamic banks. Measurement of financial performance include the results of the calculation of financial performance based on published financial reports and audited public accountant. These ratios are designed to help analysts and investors in evaluating the financial based financial statements. Bank too often use debt to fund its business activities would pose a risk to pay off its debts. Debt obligations will cause the bank to pay the entire amount of the debt plus interest on the debt to the lender.

\section{CONCLUSIONS AND SUGGESTIONS}

\subsection{Conclusion}

Based on the discussion it can be concluded that the effect on the financial performance of risk, which means that the poor financial performance can increase the risk. The results of this study are consistent with Purnamandari and Badera found that the financial performance such as BOPO is able to predict the risk of bank failure.Financial distress is affected financial performance risk. The results of this study are consistent with research Saleh and Sudiyatno, Baskoro. Risk mediating influence the financial performance of the stock price [18], [19]. The better financial performance reflects the performance of a particular period can reduce financial distress.

\subsection{Suggestion}

For Islamic banks in order to maintain financial performance has been good and to improve financial performance is not good like, so as to enhance the attractiveness of investors to invest in Islamic banks, because the rate of return will be even greater. For society, the expected results of this study are useful for prospective investors in knowing the financial performance of banks and serve as decision making of potential investors in choosing Islamic banks to invest funds. The results of this study can be used as reference for future researchers, and future researchers can fix this by examining research from other sectors, as well as add other variables that can affect the risk and financial distress.

\section{REFERENCES}

1. Hassoune, A. 2002. Islamic banks' profitability in an interest-rate cycle. International Journal of Islamic Financial Services, 4 (2), 1-13. Retrieved from http://www.ifisa.co.za/Articles/Islamic Banking/Islamic Banks Profitability in an interest rate cycle_Banking.pdf

2. Ramlan, H., \& Adnan, M. S. 2016. The Profitability of Islamic and Conventional Bank: Case Study in Malaysia. Procedia Economics and Finance, 35 (October 2015), 359-367. https://doi.org/10.1016/S2212-5671(16)00044-7.

3. Kurniawansyah, D. 2016. Profit Loss Sharing Funding dan Financing Terhadap ofitabilitas Bank Umum Syari'ah di Indonesia dengan Efisiensi dan Risiko Sebagai Mediasi, SNA, 1-26.

4. Rahman, Abdul R., \& Masngut M. Y. 2014. The use of "CAMELS" in detecting financial distress of Islamic banks in Malaysia. Journal of Applied Business Research, 30 (2), 445-452.

5. Platt, H. D., \& Platt, M. B. 2002. Predicting Corporate Financial Distress: Reflection on Choice-Based Sample Bias. Journal of Economic and Finance, 26 (2), 184-199.

6. Zaki, E., Bah, R., \& Rao, A. 2011. Assessing probabilities of financial distress of banks in UAE. International Journal of Managerial Finance, 7 (3), 304-320.

7. Ismawati, K dan Istria, P. C. 2015. Detektor Financial Distress Perusahaan Perbankan Indonesia. Jurnal Ekonomi Bisnis dan Kewirausahaan, Vol. 4, Hal. 6-29.

8. Hosen, M. N., \& Nada, S. 2013. Pengukuran Tingkat Kesehatan Dan Gejala Financial Distress Bank Umum Syariah. Jurnal Economia, 9 (2), 215-226.

9. Hanafi, Mamduh H dan A. Halim. 2007. Analisis Laporan Keuangan,.Edisi 3. Yogyakarta: Penerbit UPP STIM YKPN

10. Fahmi, Irham. 2013. Analisis Laporan Keuangan. Bandung: Alfabeta.

11. Mulyadi. 2001. Sistem Akuntansi. Edisi Tiga.Jakarta : Salemba Empat.

12. Helfert, Erich A. 2003. Technique of Financial Analysis. $11^{\text {th }}$ ed. McGraw-Hill Companies, Inc., New York. 
13. Idroes, Ferry N. 2008. Manajemen Risiko Perbankan: Pemahaman Pendekatan 3 Pilar Kesepakatan Basel II Terkait Aplikasi Regulasi dan Pelaksanaannya di Indonesia. PT. Rajagrafindo Persada. Jakarta.

14. Sholihin, Mahfud dan Dwi Ratmono. 2013. Analisis SEM-PLS dengan WarpPLS 3.0: untuk Hubungan Nonlinier dalam Penelitian Sosial Bisnis. Yogyakarta: Andi Offset.

15. Chandrarin, Grahita. 2017. Metode Riset Akuntansi Pendekatan Kuantitatif, Jakarta: Salemba Empat.

16. Kieso, Donald E., Jerry J, Weygandt, Terry D.Warfield. 2008. Akuntansi. Intermediate. Edisi 12. Jakarta: Erlangga.

17. Purnamandari, Ni Putu Lisna dan I Dewa Nyoman Badera. 2015. Kemampuan Prediksi Rasio Keuangan dan Ukuran Bank pada Risiko Gagal Bank. E Jurnal akuntansi Universitas Udayana. Vol 12. No. 2: 172-187.

18. Saleh, Amir dan Bambang Sudiyatno. 2013. Pengaruh Rasio Keuangan Untuk Memprediksi Probabilitas Kebangkrutan Pada Perusahaan Manufaktur Yang Terdaftar Di Bursa Efek Indonesia. Dinamika Akuntansi, Keuangan dan Perbankan. Vol. 1 No 2: $82-91$.

19. Baskoro, Agus Adi. 2014. Analisis Rasio-rasio Keuangan Untuk Memprediksi. Financial Distress Bank Devisa Periode 2006-2011. Journal Of Business and. Banking. Vol. 4, No. 1. May. 105-116. 